\title{
集団住宅地における配置形式と近隣関係
}

\author{
（戸建住宅の場合・その 2 )
}

\section{正会員 ○栗原嘉一郎*}

\section{§1. 研究目的亡調查概}

要 本報告注文 1 文 3 と 一連の研究をなすものであ り，以下の上らな条件の戸 建住宅群に扮いて，主婦の 近隣交際と住戸配置の関係 を調べたもので女る。すな わち調查刘象は文 2 の場合 に対して，1）公営住宅で ある，2)入居してからかな りの年月を経ている(1955 年入居）3）より高密度で ある，4）東西に長い街区 割りをした配置である，等 の特徴をるつ。図一1に調 查対象地区, 図一 2 亿その 中の対象区域住戸配置を示 した。住户型は 2 K型の 2 戸建。対象任江数は 116 戸，回収数111人。調查期 日㹸'63年11月。

\section{\$2. 調査対象省の概} 要 $($ 表一1) (表-2)

§3. 主媂の近隣關係 1 図一 3 は交際相手を 配置図の番号に従って, 縦軸に選択する側, 横禹 に選択される側として， 一覽図示したものであ る。つき合いの基準は既 報告と同様に 2 段階に設 定してある。梁い関係： ふだんから気が合って色 々な行動を斯する。浅 、関係：会えばあいさつ をかわす程度。(詳細文 1 参照)。つき合いの拡が りは，道路で囲まれたA 〜 のような同一ブロッ

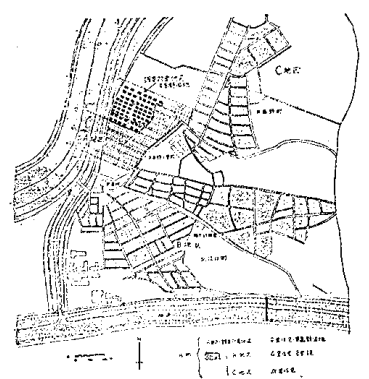

图一1 翮查刘象地区（大应 本営及附営北江口・井高野地区)

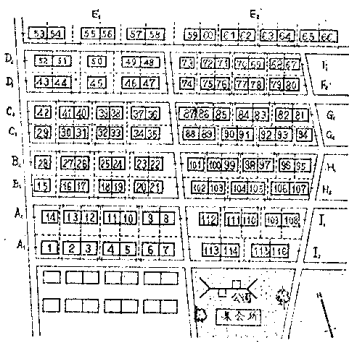

図-2 䧓查効秘区域・住 戸配置

表一1 調查刘象世蒙の家族型 ・収入・躍業

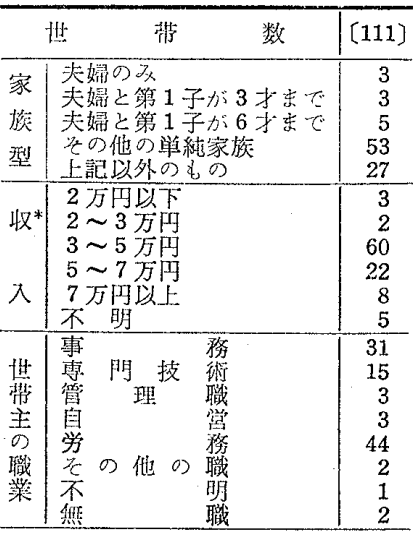

〔〕のない数值は世带数に対する\%

* 収入は家族の 1 か月当り合計収入 ボーナスも含む。

表一2 洞查対象主婦の年令・ 学歴

\begin{tabular}{|c|c|c|}
\hline \multicolumn{2}{|r|}{ 主 婦 実人 数 } & [111] \\
\hline 年 & $\begin{array}{l}20 \sim 29 \text { J } \\
30 \sim 39\end{array}$ & $\begin{array}{r}9 \\
42 \\
95\end{array}$ \\
\hline & $\begin{array}{l}40 \sim 49 \text { J } \\
50 \text { 上 }\end{array}$ & $\begin{array}{l}25 \\
23\end{array}$ \\
\hline & 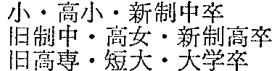 & \\
\hline & 不明 & \\
\hline
\end{tabular}

数偵な实人数に対する\%
$*$ 大阪市立大学助教授 $\cdot$ 工博 建築事務所員
多胡 進**

同

中村恭三****

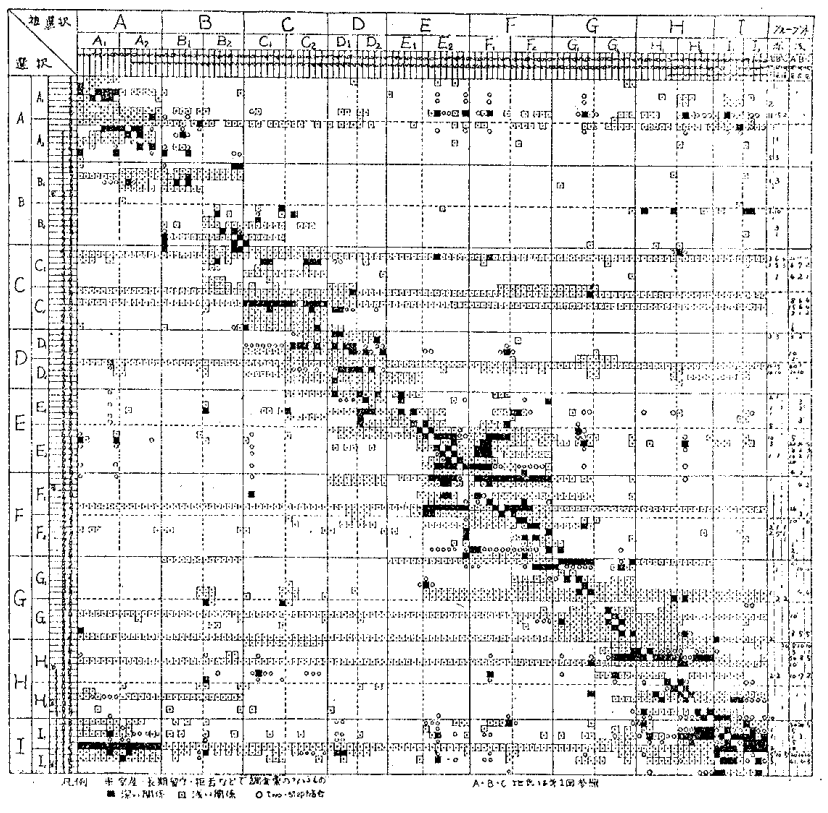

图-3 戸建住宅の近筷関係

表一3 つき合い人数とその分布

\begin{tabular}{l|c|c}
\hline & 深 い関 係 & 浅 い関 係*4 \\
\hline 1人当りつき合い人数 & $5.6 人$ & 36.3 人 \\
グループ内率*1 & $60 \%$ & $74 \%$ \\
同ープロック内摔*2 & $33 \%$ & $21 \%$ \\
向い合せ内率*3 & $21 \%$ & $20 \%$ \\
\hline
\end{tabular}

*1 調查地区内のつき合い総昷のろち，グループ内のつき合いが占める 割合。ただしグルーブとは調查対象区域の簿国省いう。

*2 グループ内のつき合い人数に效古局一ブロック内のつき何以人数 の割合。ただしブロックとは道路で国まれた区画内。

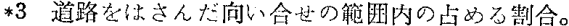

*4この中心は澡い関係当含む。

クないしは $\mathrm{A}_{2} \mathrm{~B}_{1}, \mathrm{~B}_{2} \mathrm{C}_{1} \sim \mathrm{H}_{2} \mathrm{I}_{1}$ のような同一道路をは さんだ向い合せの䇛畔に掠いて密度が高く，1つのまと まりをみ技ている。その他の場所にも浅い関係のつき合 いがかなりある。

$2^{\circ}$ 表一 3 は図一 3 を集計したものである。1）つき 合い人数は文 1 〜文 3 の場合上り深、関係・浅い関係上 もに多くなっている。これは居住期間が長いことや，戸 建でも密度が高くかなりオープンな配置であることなど によると思われる。2）グループ内のつき命いの占める 割合法浅い関係の方が深、関係よりも大きくなってい る。3）道路で囲まれた区画内の結びつきの方が，道を はさむ向い合せの結びつきよりやや強い。

[文献]

1）諭報笌69号昭36年10月，集団住宅地における配置形式と 近隣関係, 梠原・多胡・藤田・大薮

2）諭報第38号昭38年 9 月，同上（六建住宅場合)，梁原・多 胡・岩永

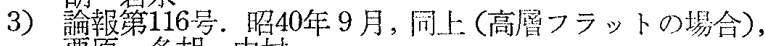
栗原・多胡・中村 